\title{
Sigmoid Sinus Septic Thrombophlebitis due to Chronic Mastoiditis and Otitis Media: A Case Report
}

\author{
Soheil Ebrahimpour ${ }^{1}$, Mahmoud Sadeghi-Haddad-Zavareh¹, Zeinab Mohseni Afshar², \\ Arefeh Babazadeh ${ }^{1}$ \\ ${ }^{1}$ Infectious Diseases and Tropical Medicine Research Center, Health Research Institute, \\ Babol University of Medical Sciences, Babol, I. R. Iran \\ ${ }^{2}$ Clinical Research Development Center, Imam Reza Hospital, Kermanshah University of Medical Sciences, \\ Kermanshah, I. R. Iran
}

\section{SUMMARY}

Sigmoid sinus septic thrombosis is an infrequent complaint that may lead to extensive morbidity and mortality. We report a case with septic thrombosis of the sigmoid sinus caused by chronic mastoiditis and otitis media. A 29-year-old male presented with a 14-day history of tinnitus and true vertigo with a gradually developing swelling on the right side of the neck. Neck computerized tomography (CT) scan found a mastoid abscess. Also, magnetic resonance imaging (MRI) showed an enlargement of the sigmoid sinus veins that was characteristic of septic thrombophlebitis (SSST). The patient's condition and his symptoms and signs improved under antibiotic therapy and his mastoid mass size decreased gradually. In sigmoid sinus septic thrombosis, timely diagnosis and quick management, using broad-spectrum intravenous antibiotics, are critical for case recovery.

Key words: sigmoid sinus, septic thrombosis, chronic mastoiditis, otitis media, computerized tomography

Corresponding author:

Arefeh Babazadeh

E-mail: drbabazadeh.a@yahoo.com. 


\section{INTRODUCTION}

Sigmoid sinus thrombosis is a rare condition, usually caused by thrombophilia, head injuries, some malignancies, intravenous (IV) drug use, and of course, mainly by infections $(1,2)$. When the etiology is infectious, it is called sigmoid sinus septic thrombosis (SSST), and acute or chronic otitis media are the most common causes of this condition (2). Common pathogens responsible for this condition are Staphylococcus aureus and $\beta$-haemolytic Streptococcus (3). Septic sigmoid sinus thrombosis may have extensive morbidity and mortality.

The most major mechanisms of this condition are the spread of infection from the tympano mastoid part of the ear, via septic granulation tissue covering the sinus cavities (4). Early diagnosis and rapid treatment are crucial to improving the prognosis of this potentially lethal disease. The diagnosis is based on clinical manifestations and confirmed by imaging (5).

However, timely diagnosis of septic sigmoid sinus thrombosis is a challenge and very difficult because of its nonspecific manifestations (6). Since the use of antibiotics in humans has become commonplace, the mortality rate of sigmoid sinus thrombosis has decreased considerably. Usually, administered therapy of SSST is broad-spectrum antibiotics that traverse the blood-brain barrier. Also, anticoagulant therapy is well indicated in adults but controversial in children (7). Here, we report a case of septic thrombosis of the sigmoid sinus caused by chronic otitis media and mastoiditis.

\section{CASE REPORT}

A 29-year-old male presented with a twoweek history of tinnitus and true vertigo with a gradually developing swelling on the right side of the neck. He complained of pain and purulent discharge from his right ear and received antibiotic therapy prior to this presentation but his condition did not resolve. He reported a history of right ear trauma and perforation of the tympanic membrane in the childhood and underwent surgical repair a few years earlier. Moreover, he had recurrent episodes of otitis media in the past years and was hospitalized for the last episode two months prior to his presentation. His vital signs were stable and the only prominent signs discovered were an induration at the superior portion of the sternocleidomastoid muscle, and submandibular and submastoid tenderness and swelling. His neurological findings were normal. Laboratory tests were as follows: white blood cell (WBC), 8600 cells $/ \mathrm{ml}^{3}$; hemoglobin, 12.8 $\mathrm{g} / \mathrm{dL}$; platelet count, $232000 \mathrm{~g} / \mathrm{dl}$; creatinine (Cr): 0.9

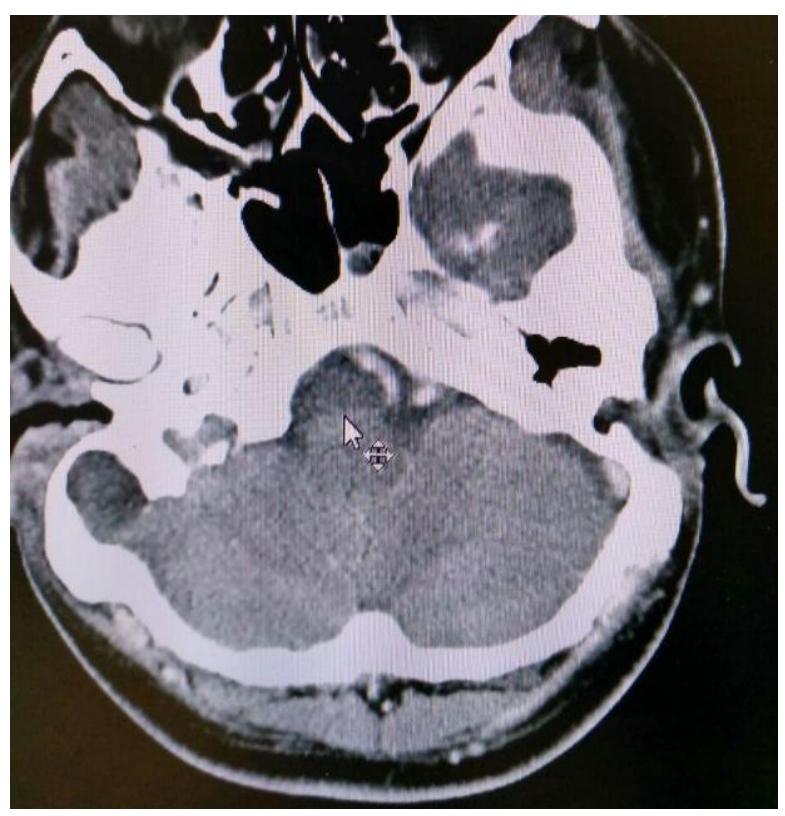

Figure 1: Neck computerized tomography (CT) scan found a mastoid abscess

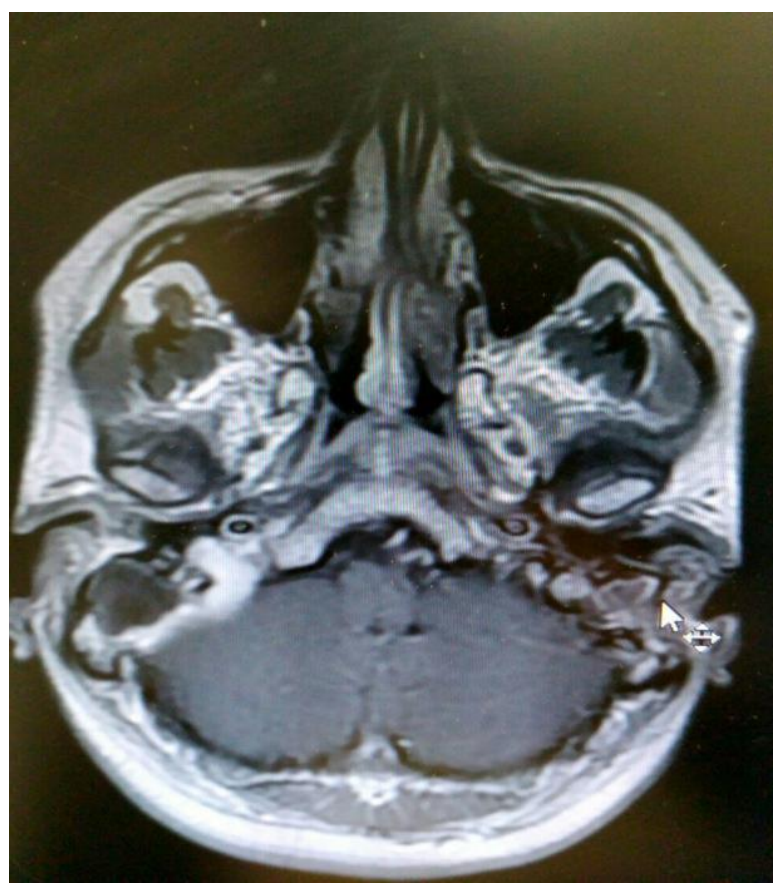

Figure 2: Magnetic resonance imaging (MRI) showed an enlargement of the sigmoid sinus veins 
$\mathrm{mg} / \mathrm{dl}$; with normal electrolytes. His neck ultrasonography showed some lymphadenopathies and surrounding echogenic fat stranding with a heterogenic hypoechoic lesion with lobulated margin and vascular flow with dimension of 16,21 , and 28 $\mathrm{mm}$ at the posterior-superior portion of SCM muscle.

Neck computerized tomography (CT) scan found a mastoid abscess (Figure 1). According to a neurosurgery consult, magnetic resonance imaging (MRI) was requested that showed an enlargement of the sigmoid sinus veins, which was characteristic of septic thrombophlebitis (SSST) (Figure 2). After brain MRI and neck CT scan, he was finally diagnosed with septic thrombosis on the right sigmoid sinus and a concurrent mastoid abscess, so broadspectrum antibiotic therapy was administered; vancomycin $1 \mathrm{~g}$ every $12 \mathrm{~h}$ and meropenem $1 \mathrm{~g}$ every $8 \mathrm{~h}$. Ear-Nose-Throat (ENT) consult advocated core needle biopsy (CNB) or fine-needle aspiration (FNA) with ultrasonography guide for a mastoid abscess. The patient's condition improved considerably and his symptoms and signs ameliorated under antibiotic therapy and his mastoid mass size decreased gradually without surgical intervention.

\section{DISCUSSION}

Cerebral venous thrombosis is a moderately uncommon but important neurologic disorder that is curable with fast diagnosis and suitable therapy.

The sigmoid sinus with some special anatomical conditions of the mastoid bone is a predisposing factor of the extent of infection from the middle ear, leading to thrombophlebitis (8).

Nowadays, chronic suppurative otitis media (CSOM) and cholesteatoma are responsible for most of the intracranial complications as SSST and these complications occur more commonly in the first three decades of life, especially in men $(9,10)$. Our patient was also a known case of CSOM that developed SSST.

Generally, sinus thrombosis occurs by gradual bone erosion of the mastoid bone covering the sinus, either due to cholesteatoma or granulomatous situations, forming a perisinus abscess (11).

The pressure on the bone by abscess, causing necrosis on the anterior portion of the sinus, with adherence of platelets and red blood cells (RBCs), leads to the formation of a thrombus.
The current case had a right CSOM with sigmoid sinus thrombosis and his manifestations were typical for SSST.

The most frequent manifestation sigmoid sinus thrombosis is fever, associated with otorrhea, otalgia and postauricular edema which were evident in this patient (10). The headache is a very common neurologic symptom in these cases but was absent in our patient.

Evaluation of the lab data, such as neutrophilia greater than $20.000 \mathrm{~mm}^{3}$ with anemia did not help in the diagnosis in our patient. A lumbar puncture may also provide both diagnostic and therapeutic value but may be dangerous because of the risk of brain herniation. We did not do this procedure but, if we had done so, we might have discovered lymphocytic pleocytosis, a high red blood cell count and high protein. Because of the nonspecific nature and symptoms, cerebral venous thrombosis is often misdiagnosed (about $60 \%$ of cases) or its diagnosis is delayed (12). Therestore the median delay from the onset of symptoms to diagnosis is four weeks (13).

Radiological procedures are one of the basics of exact diagnosis. CT is useful for diagnosing bone devastation, and there is an indication in suspected cases of intracranial complications. In this case, the CT scan helped us to diagnose mastoiditis. However, MRI has proven to be the diagnostic procedure of choice in detecting SSST (14). In our patient, different radiological procedures were helpful in the diagnosis.

The treatment of cerebral septic venous sinus thrombosis includes broad-spectrum antibiotic therapy and also surgical drainage of the infected site, with probable removal of the obstructing clot. Fortunately, due to our patient's typical manifestations and prompt imaging, early diagnosis was achieved and therefore, antibiotic therapy alone was sufficient without any surgical intervention.

\section{CONCLUSION}

Chronic mastoiditis and otitis media are known to be common causes of septic thrombosis of the sigmoid sinus. In sigmoid sinus septic thrombosis, timely diagnosis by CT scan or MRI and quick management using broad-spectrum intravenous antibiotics are very important for the patient recovery. 


\section{Acknowledgement}

The authors thank to the Department of Infectious diseases of Babol University of Medical sciences, Iran and Marzieh Nourollahzadeh for her guidance as a translator of this article.

\section{Conflict of interests}

The authors report no conflict of interest.

\section{References}

1. Sasidharan PK. Cerebral vein thrombosis misdiagnosed and mismanaged. Thrombosis 2012; 2012:210676-.

https://doi.org/10.1155/2012/210676

2. Penido Nde O, Toledo RN, Silveira PA, at al. Sigmoid sinus thrombosis associated to chronic otitis media. Braz J Otorhinolaryngoly 2007;73:16570.

https://doi.org/10.1016/S1808-8694(15)31062-4

3. Leo QJN, Bolger DT, Jr. Septic cavernous sinus thrombosis due to Campylobacter rectus infection. BMJ case reports 2014;2014:bcr2013203351. https://doi.org/10.1136/bcr-2013-203351

4. Scherer A, Jea A. Pediatric Otogenic Sigmoid Sinus Thrombosis: Case Report and Literature Reappraisal. Global Pediatric Health 2017;4:2333794X17738837-2333794X. https://doi.org/10.1177/2333794X17738837

5. Raja K, Parida PK, Alexander A, Surianarayanan G. Otogenic Lateral Sinus Thrombosis: A Review of Fifteen Patients and Changing Trends in the Management. Int Arch Otorhinolaryngol 2018;22:208-13. https://doi.org/10.1055/s-0037-1604198

6. Viswanatha B, Thriveni CN, Naseeruddin K. Nonseptic and septic lateral sinus thrombosis: a review. Indian journal of otolaryngology and head and neck surgery: official publication of the Assoc Otolaryngologists India 2014;66:10-5. https://doi.org/10.1007/s12070-011-0422-4

7. Zanoletti E, Cazzador D, Faccioli C, at al. Intracranial venous sinus thrombosis as a complication of otitis media in children: Critical review of diagnosis and management. Int J Pediatric Otorhinolaryngol 2015;79:2398-403. https://doi.org/10.1016/j.ijporl.2015.10.059

8. Chiewvit P, Piyapittayanan S, Poungvarin N. Cerebral venous thrombosis: diagnosis dilemma. Neurol Int 2011;3:e13-e. https://doi.org/10.4081/ni.2011.e13

9. Singh GB, Arora R, Garg S, at al. Septic Lateral Sinus Thrombosis: Sinus Exploration Is Unnecessary. Case Rep Otolaryngol 2016;2016:4349538-. https://doi.org/10.1155/2016/4349538

10. Yeoh XY, Lim PS, Pua KC. Case of Chronic Otitis Media with Intracranial Complication and Contralateral Extracranial Presentation. Case Reports in Otolaryngol 2016;2016:7810857-. https://doi.org/10.1155/2016/7810857

11. Kaplan D, Kraus M, Puterman M, at al. Otogenic lateral sinus thrombosis. Int $\mathrm{J}$ Pediatric Otorhinolaryngol 1999;49(3):177-83 . https://doi.org/10.1016/S0165-5876(99)00202-5 
12. Shah CT, Rizqallah JJ, Oluwole O, at al. Delay in diagnosis of cerebral venous and sinus thrombosis: successful use of mechanical thrombectomy and thrombolysis. Case Rep Med 2011;2011:815618https://doi.org/10.1155/2011/815618

13. Weon YC, Marsot-Dupuch K, Ducreux D, Lasjaunias P. Septic thrombosis of the transverse and sigmoid sinuses: imaging findings. Neuroradiol 2005;47:197-203.

https://doi.org/10.1007/s00234-004-1313-0

14. Viswanatha B, Naseeruddin K. Lateral sinus thrombosis in otology: a review. Mediterr J Hematol Infect Dis 2010;2:e2010027-e.

https://doi.org/10.4084/mjhid.2010.027 


\title{
Septični tromboflebitis sigmoidnog sinusa usled hroničnog mastoiditisa i upale srednjeg uva: prikaz slučaja
}

\author{
Soheil Ebrahimpour ${ }^{1}$, Mahmoud Sadeghi-Haddad-Zavareh ${ }^{1}$, \\ Zeinab Mohseni Afshar ${ }^{2}$, Arefeh Babazadeh ${ }^{1}$ \\ ${ }^{1}$ Istraživački centar za infektione i tropske bolesti, Zdravstveni istraživački institute, \\ Univerzitet medicinski nauka u Babolu, Babol, Islamska Republika Iran \\ ${ }^{2}$ Klinički istraživački centar za razvoj, Bolniva Imam Reza, Univerzitet medicinskih nauka u Kermanshahu, \\ Kermanshah, Islamska Republika Iran
}

\section{SAŽETAK}

Septični tromboflebitis sigmoidnog sinusa je retka pojava koja može da dovede do značajnih morbiditeta i mortaliteta. U radu je dat prikaz slučaja sa septičnom trombozom sigmoidnog sinusa izazvanom hroničnim mastoiditisom i upalom srednjeg uva. Prikazan je slučaj dvadesetdevetogodišnjeg muškarca koji je u anamnezi opisao prethodno dvonedeljno trajanje zujanja u ušima i vrtoglavice, pri čemu se otok na desnoj strani vrata postepeno uvećavao. Kompjuterizovana tomografija vrata pokazala je postojanje mastoidnog apcesa. Takođe, magnetna rezonanca ukazala je na uvećanje vena sigmoidnog sinusa, što je karakteristično za septični tromboflebitis. Zdravsteno stanje bolesnika kao i simptomi i znaci poboljšali su se nakon primene antibiotske terapije, dok se veličina mastoidne mase postepeno smanjila. U slučaju septične tromboze sigmoidnog sinusa, pravovremena dijagnostika i brzo lečenje, pomoću intravenskih antibiotika širokog spektra, ključni su za opravak u ovakvim slučajevima.

Ključne reči: sigmoidni sinus, septična tromboza, hronični mastoiditis, upala srednjeg uva, kompjuterizovana tomografija 